\section{BDS, FCPS}

Assistant Professor

Department of Prosthodontics

College of Dentistry, King Khalid

University,

Abha Kingdom of Saudi Arabia.

2. BDS, FCPS

Associate Professor

Department of Prosthodontics

Sindh Institute of Oral Health

Sciences

Jinnah Sindh Medical University,

Karachi

3. BDS, FCPS

Assistant Professor

Department of Prosthodontics

Bibi Asifa Dental College, Larkana.

4. BDS, MCPS

Associate Professor

Department of Prosthodontics

Dow International Dental College

Dow University of Health Sciences,

Karachi.

5. BDS, FCPS

Associate Professor

HOD Oral Maxillofacial Surgery and Principal

Bibi Aseefa Dental College, Larkana.

6. BDS

Lecturer

Department of Oral Maxillofacial

Surgery

Bibi Aseefa Dental College, Larkana.

Correspondence Address:

Dr. Gotam Das

Sindh Dental Clinic Newtown

Mirpurkhas Sindh Pakistan.

drgotam2000@gmail.com

Article received on:

02/10/2018

Accepted for publication:

22/02/2019

Received after proof reading:

$31 / 07 / 2019$

\section{CROSS INFECTION CONTROLIN PRIVATE DENTAL PRACTICE IN KARACHI, SINDH.}

\begin{abstract}
Gotam Das', Imran Samejo², Shabir Ahmed ${ }^{3}$, Bushra Jabeen ${ }^{4}$, Muhammad Ilyas Shaikh ${ }^{5}$, Kinza Mushtaque ${ }^{6}$

ABSTRACT... The Aim of this study was to assess that what measures were taken routinely by private dental practitioners regarding cross infection control. Study Design: Cross sectional study. Setting: Private dental practitioners in Karachi. Period: 01-04-2018 to 30-09-2018. Materials and Methods: A questionnaire comprised of 10 questions was prepared regarding measures taken for infection control in private dental practice. The questionnaire was distributed randomly among 130 private dental practitioners by hand to carry out a cross sectional study on cross Infection control among the private dental practitioners in Karachi. The each question had two options (YES OR NO), and the respondents had to select one of the two. Results: The questionnaire was sent to 130 private dental practitioners, out of which 111 dentists responded and returned the questionnaire. The response rate was $85 \%$. Following are the results obtained. $85 \%$ of participants asked detailed medical history. Majority of dentists $(78 \%)$ were immunized against hepatitis B. $95 \%$ of the participants stated that they wore gloves during dental treatment and change on each patient. Mask was worn and changed on each patient by $67 \%$ of dentists during treatment. Protective eye glasses and protective face shield were worn by $20 \%$ and $2 \%$ of respondents respectively during dental treatment. Majority of dentists (84\%) used autoclave to sterilize the hand piece and $16 \%$ dentists used sterilized hand piece on each patient. $100 \%$ participants changed instruments such as extraction instruments, saliva ejector, hand piece, impression trays on each patient. Only 3\% of participant disinfected the impression before sending to laboratory. Only $17 \%$ participants used special container to disposal off sharp objects. Conclusion: Cross infection control measures need to be improved in private dental practice.
\end{abstract}

Key words: Autoclave, Cross Infection Control, Private Dental Practice, Universal precaution

Article Citation: Das G, Samejo I, Ahmed S, Jabeen B, Shaikh MI, Mushtaque K. Cross infection control in private dental practice in Karachi, Sindh. Professional Med J 2019; 26(8):1354-1358. DOI: 10.29309/TPMJ/2019.26.08.17

\section{INTRODUCTION}

Cross infection refers to the transfer of microorganisms between people, either from air, direct contact, surgery surfaces, dental instruments and dental appliances. Cross infection control is required in any health care setup. ${ }^{1}$ Hospital environments can be a source of transfer of pathogens; between patients, patient to doctor and among the staff, if infection control is not practiced adequately. ${ }^{2}$ The infective agent can be transmitted via instruments contaminated with blood, saliva and tissue debris. ${ }^{1}$ Cross infection control is a vital part of dental education and emphasis should be placed on its importance during the training of future dentists, in order for them to adopt the proper attitude towards infection control measures. ${ }^{3}$ Hepatitis B, Tuberculosis, HIV are among the highly infectious diseases a doctor comes across, it is necessary to protect themselves and others from these diseases. ${ }^{4}$ When compliance is lacking it results in the compromising of safety for both the dental personnel and the patients. ${ }^{5}$ Hepatitis $B, C$ and Tuberculosis have been proven to be transmissible from patients when cross infection control practice is sub-standard. ${ }^{4}$ The Dental clinic is an environment where infections can be transmitted easily. ${ }^{6}$ Dental care professionals are more prone for the exposure of any infectious materials, including body fluids such as blood, droplets either directly through needle stick injury, splash or indirectly through contamination 
of instruments or equipment. ${ }^{7}$ Every healthcare system should have an infection control program. All hospitals and dental clinics should have cross infection control programs in order to protect both patients and members of the dental team from contracting infections during dental procedures. ${ }^{8}$ The prevention process comprises of hand washing, using personal protective equipment, disinfection and sterilization, and Vaccinations. Personal protection procedures are most important in dental clinics to avoid transmission of infectious diseases. ${ }^{9}$ Therefore, gloves, sterile masks and eye protection should be worn. Also thorough hand-washing with an anti-bacterial soap is advisable as it reduces the risk of crossinfection further. ${ }^{10}$ All instruments must first be cleaned, disinfected, and then sterilized using an autoclave (with a minimum temperature of $115 \mathrm{C}$ for a duration of 30 minutes. Hand-pieces must be sterilized by autoclaving after each patient. ${ }^{11}$ The storage of instruments after sterilization is equally as important as the sterilization itself. They should be stored in a clean, covered and sterile environment and should not be handling without wearing protective clothing e. g. gloves (which should be well fitted and not powdered). ${ }^{12}$ In certain circumstances disposable items and instruments must be used e. g. impression trays and beakers. ${ }^{13}$ Sharps injuries are a major factor by which cross-infection may occur, especially of the more serious diseases.Sharp instruments such as surgical blades, needles are required to be disposed into puncture proof containers in order to reduce the possibility of needle stick injuries. ${ }^{8}$ Investigations must be carried out when there are suspicions of spread of infection or when there is evidence of it. ${ }^{14-15}$ Infection control is a very important area of dentistry and should not be ignored as it can have serious implications on the reputation of dentistry as a profession. ${ }^{16-17}$ Patients deserve the right to be treated in a safe environment; this should involve reducing the risk of infection to an acceptable level. The dental staff also has a right to be protected from the infections acquired at work. ${ }^{18}$ This requires the dental hospital to implement a infection control program that respects their right as a part of its ethical, moral and legal responsibility. ${ }^{19}$

\section{MATERIALS AND METHODS}

A cross sectional study was conducted among Private dental practitioners in Karachi. A questionnaire comprised of 10 questions was prepared regarding measures taken for infection control in private dental practice. The questionnaire was distributed randomly among 130 private dental practitioners by hand to carry out a cross sectional study on cross Infection control among the private dental practitioners in Karachi. 111 practioners responded and returned the questionnaire. The response rate was $85 \%$. The each question had two options (YES OR $\mathrm{NO}$ ), and the respondents had to select one of the two. Statistical Package for the Social Sciences (SPSS) version 17.0 was used for data analysis.

\section{RESULTS}

The questionnaire was sent to 130 private dental practitioners, out of which 111 dentists responded and returned the questionnaire. The response rate was $85 \%$. Following are the results obtained. $85 \%$ of participants asked detailed medical history.

Majority of dentists (78\%) were immunized against hepatitis B. $95 \%$ of the participants stated that they wore gloves during dental treatment and change on each patient.

Mask was worn and changed on each patient by $67 \%$ of dentists during treatment. Protective eye glasses and protective face shield were worn by $20 \%$ and $2 \%$ of respondents respectively during dental treatment.

Majority of dentists (84\%) used autoclave to sterilize the hand piece and $16 \%$ dentists used sterilized hand piece on each patient.

$100 \%$ participants changed instruments such as extraction instruments, saliva ejector, hand piece, impression trays on each patient. Only $3 \%$ of participant disinfected the impression before sending to laboratory.

Only $17 \%$ participants used special container to disposal off sharp objects. 


\begin{tabular}{|c|c|c|c|}
\hline Question & $\begin{array}{c}\text { Response } \\
\text { Option }\end{array}$ & Frequency & Percentage \\
\hline Do you take medical history from each patient? & $\begin{array}{l}\text { Yes } \\
\text { No }\end{array}$ & $\begin{array}{l}95 \\
16\end{array}$ & $\begin{array}{l}85 \\
15\end{array}$ \\
\hline Are you vaccinated against hepatitis $B$ ? & $\begin{array}{l}\text { Yes } \\
\text { No }\end{array}$ & $\begin{array}{c}101 \\
10\end{array}$ & $\begin{array}{l}91 \\
09\end{array}$ \\
\hline Do you wear and change gloves routinely during treatment on each patient? & $\begin{array}{l}\text { Yes } \\
\text { No }\end{array}$ & $\begin{array}{c}105 \\
06\end{array}$ & $\begin{array}{l}95 \\
05\end{array}$ \\
\hline Do you wear mask before treating patient? & $\begin{array}{l}\text { Yes } \\
\text { No }\end{array}$ & $\begin{array}{l}75 \\
36\end{array}$ & $\begin{array}{l}67 \\
33\end{array}$ \\
\hline Do you wear protective eye wear routinely in treating patients? & $\begin{array}{l}\text { Yes } \\
\text { No }\end{array}$ & $\begin{array}{l}22 \\
89\end{array}$ & $\begin{array}{l}20 \\
80\end{array}$ \\
\hline $\begin{array}{l}\text { What method do you use in sterilization of hand pieces? } \\
\text { a) Autoclave } \\
\text { b) Disinfection }\end{array}$ & $\begin{array}{l}\text { Yes } \\
\text { No }\end{array}$ & $\begin{array}{l}94 \\
17\end{array}$ & $\begin{array}{l}84 \\
16\end{array}$ \\
\hline Do you use sterilized hand piece for each patient? & $\begin{array}{l}\text { Yes } \\
\text { No }\end{array}$ & $\begin{array}{l}18 \\
93\end{array}$ & $\begin{array}{l}16 \\
84\end{array}$ \\
\hline $\begin{array}{l}\text { Do you change sterilized instruments on each patient? } \\
\text { a) Forceps } \\
\text { b) impression trays } \\
\text { c) Saliva Ejector }\end{array}$ & $\begin{array}{l}\text { Yes } \\
\text { No }\end{array}$ & $\begin{array}{l}88 \\
23\end{array}$ & $\begin{array}{l}80 \\
20\end{array}$ \\
\hline Do you disinfect impressions before sending to laboratory? & $\begin{array}{l}\text { Yes } \\
\text { No }\end{array}$ & $\begin{array}{l}23 \\
88\end{array}$ & $\begin{array}{l}03 \\
97\end{array}$ \\
\hline Do you use special container for disposal of sharp objects? & $\begin{array}{l}\text { Yes } \\
\text { No }\end{array}$ & $\begin{array}{l}17 \\
94\end{array}$ & $\begin{array}{l}15 \\
85\end{array}$ \\
\hline
\end{tabular}

\section{DISCUSSION}

The Dental clinic is an environment where infections can be transmitted easily. ${ }^{6}$ Dental care professionals are more prone for the exposure of any infectious materials, including body fluids such as blood, droplets either directly through needle stick injury, splash or indirectly through contamination of instruments or equipment. ${ }^{7}$ Every healthcare system should have an infection control program.

Detailed medical history is helpful in order to prevent pathogen transfer from patient to patient or from patient to the doctor/staff and also among the staff. Current study showed that detailed medical history was asked by majority $85 \%$ respondents. This result is almost similar to study conducted in Pakistan and Saudi Arabia where $98 \%$ and $93 \%$ of respondents asked detailed medical history respectively before starting dental treatment. ${ }^{9,14}$ However this finding is in contrast with studies conducted in Lebanon and Jordan, where $61 \%$ and $77 \%$ respondents asked routine medical history before starting the treatment respectively. ${ }^{4,12}$

Hepatitis B, Tuberculosis, HIV are among the highly infectious diseases a doctor comes across, it is necessary to protect themselves and others from these diseases. When compliance is lacking it results in the compromising of safety for both the dental personnel and the patients. The dental staff also requireshaving vaccinations on order to prevent transmission of the diseases to the patients. In this study $91 \%$ respondents were immunized against hepatitis $B$. These results are coinciding with previous studies conducted in Pakistan, Scotland and Canada, where $96 \%, 88 \%$, and $92 \%$ respondents were immunized against hepatitis B respectively. ${ }^{9,15,16}$ Whereas result of current study in contrast with a previous study conducted in Jordan where $36 \%$ respondents were immunized against hepatitis $\mathrm{B} .{ }^{12}$

Dental health care personnel are required to wear Personal Protective Equipment, including; gloves, masks, face shields and protective eye wear. Present study showed that $95 \%$ respondents wore 
gloves while treating patients. A study conducted in Saudi Arabia in which $100 \%$ dentist wore gloves during treatment. ${ }^{14}$ Few other Studies conducted in Pakistan, Kuwait, Canada and Jordan showed that $98 \%, 75 \%, 92 \%$ and $81 \%$ dentists wore gloves during treatment respectively. ${ }^{9,12,16,17}$

This study revealed that $67 \%$ respondents wore mask during treatment and change on each patient. Almost same results are found in previous studies, where $74 \%$ in Pakistan, $75 \%$ in Kuwait, $74 \%$ in Canada and $64 \%$ respondents in New Zealand respondents wore gloves during treatment and change on each patient. 9,12,17,18 $^{2}$

In current study $20 \%$ of respondents wore eye protection during treatment. This result is almost similar to study conducted in Pakistan where $40 \%$ of respondents wore eye protection during treatment. ${ }^{9}$ However this finding is in contrast with study conducted in Canada where $84 \%$ of respondents wore eye protection. ${ }^{16}$ Similar results are found in other studies conducted in Kuwait, New Zealand and Saudi Arabia where higher number of respondents than respondents of present study wore eye protection. ${ }^{14,17,18}$ It could be due to lack of knowledge regarding cross infection control in respondents in present study or negligence by respondents.

Impressions must be disinfected before sending to laboratory. These impressions contain blood and saliva which are main source of cross infection. Only $3 \%$ of respondents disinfected the impressions before sending to laboratory. This is in agreement to study conducted in Jordan where less number of respondents (18\%) disinfected the impression prior to sending laboratory. ${ }^{12}$ The finding of current study is in contrast with Studies conducted in Pakistan and Durban, where $67 \%$ and $58 \%$ of respondents disinfected the impressions before sending to laboratory respectively..$^{9,19}$

All instruments must first be cleaned, and then sterilized using an autoclave. Hand-pieces must be sterilized by autoclaving after each patient. Majority of respondents (30\%) in this study used autoclave to sterilize the hand piece. Remaining
$70 \%$ dentists disinfected the hand piece. However the result of this study in agreement with studies conducted in Saudi Arabia and Jordan where $42 \%$ and $38 \%$ dentists used autoclave to sterilized hand piece respectively. ${ }^{12,14}$

Sharp instruments such as surgical blades, needles are required to be disposed into puncture proof containers in order to reduce the possibility of needle stick injuries. About $15 \%$ of participants had special container for disposal of needles and sharp objective. In comparison to present study, $60 \%$ in Pakistan, 32\% in Jordan and 56\% in Saudi Arabia respondents used special container for disposal of needles and sharp objectives. .,12,14 $^{2}$

This study showed that $100 \%$ respondents changed instruments such as extraction instruments, handpiece and saliva ejector on each patient. Almost same results are found in studies conducted in Jordan and Saudi Arabia where majority of respondents changed instruments on each patient. ${ }^{12,14}$ However this finding is in contrast with study conducted in Pakistan, where $50 \%$ of respondents changed hand pieces between patients. ${ }^{9}$ Again it could be due to lack of knowledge regarding cross infection control in respondents in present study or negligence by respondents.

\section{CONCLUSION}

Measures taken by private dental practitioners for cross infection control in majority of the private dental practices need to be improved. Cross infection control courses and current infection control recommendation must be attended by dentist regularly. Infection control manual must be developed and distributed to dentists in order to prevent transmission of infection.

\section{Copyright@ 22 Feb, 2019.}

\section{REFERENCES}

1. Ibrahim NK, Alwafi HA, Sangoof SO, Turkistani AK, Alattas BM. Cross-infection and infection control in dentistry: Knowledge, attitude and practice of patients attended dental clinics in King Abdulaziz University Hospital, Jeddah, Saudi Arabia. J Infect Public Health 2017; 10:438-445.

2. Sebastiani FR, Dym H, Kirpalan T. Infection control in the dental office. Dent Clin North Am 2017; 2:435-457. 
3. Kelsch N, Davis CA, Essex G, Laughter L, Rowe DJ. Effects of mandatory continuing education related to infection control on the infection control practices of dental hygienists. Am J Infect Control 2017; 8:926-8.

4. Dagher J, Sfeir C, Abdallah A, Majzoub Z. Infection control measures in private dental clinics in Lebanon. Int J Dent. 2017; 1-11.

5. Smith AJ et al. Patients' perception of infection prevention in dental practice. Am J Infect Control 2014; 3:337-9.

6. Sammy KC, Benjamin SN. Infection control mechanisms employed by dental laboratories to prevent infection of their dental technicians/ technologists. J Oral Health CraniofacSci 2016; 1: $1-11$.

7. Vázquez Rodríguez I et al. Quality of cross-infection control in dental laboratories. A critical systematic review. Int J Qual Health Care 2018; 7:496-507.

8. Cleveland $\mathrm{JL}$ et al. Transmission of blood-borne pathogens in US dental health care settings: 2016 update. J Am Dent Assoc 2016; 9:729-38.

9. Mohiuddin, Dawani N. Knowledge, attitude and practice of infection control measures among dental practitioners in public setup of Karachi, Pakistan: Cross-sectional survey. J Dow Uni Health Sci 2015; 9: 89-94.

10. Banglani MA, Priya, Punjabi SK, Banglani M. Cross infection control - a study. Pak Oral Dent J 2016; 2:286-8.

11. Ratnayake $D$ et al. Awareness of risk of cross-infection and infection-control measures among patients attending University Dental Hospital, Peradeniya, Sri Lanka. J Investig Clin Dent 2018; 1:1-4.
12. Al-Omari MA1, Al-Dwairi ZN. Compliance with infection control programs in private dental clinics in Jordan. J Dent Educ2005; 6:693-8.

13. McCarthy GM, Koval JJ, John MA, MacDonald JK. Infection control practices across Canada: Do dentists follow the recommendations?. J Can Dent Assoc 1999; 9:506-11.

14. Al-Rabeah A1, Moamed AG. Infection control in the private dental sector in Riyadh. Ann Saudi Med 2002; 2:13-7.

15. Gore SM, Felix DH, Bird AG, Wray D. Occupational risk and precautions related to HIV infection among dentists in the Lothian region of Scotland. J Infect 1994; 28:209-22.

16. McCarthy GM, MacDonald JK. The infection control practices of general dental practitioners. Infect Control Hosp Epidemiol 1997; 18:699-703.

17. Morris E, Hassan FS, AI Nafisi A, Sugathan TN. Infection control knowledge and practices in Kuwait: A survey on oral health care workers. Saudi Dent J 1996; 8:1926.

18. Treasure P, Treasure ET. Survey of infection control procedures in New Zealand dental practices. Int Dent J 1994; 4:342-8.

19. Yengopal V, Naidoo S, Chikte UM. Infection control among dentists in private practice in Durban. SADJ 2001; 12:580-4.

20. Anders PL, Townsend NE, Davis EL, McCall WD Jr. Observed infection control compliance in a dental school: A natural experiment. Am J Infect Control 2016; 9:153-6.

\begin{tabular}{|c|l|l|}
\hline \multicolumn{3}{|c|}{ AUTHORSHIP AND CONTRIBUTION DECLARATION } \\
\hline Sr. \# & \multicolumn{1}{|c|}{ Author-s Full Name } & Contribution to the paper \\
\hline 1 & Gotam Das & Data collection. \\
\hline 2 & Imran Samejo & Data collection. \\
\hline 3 & Shabir Ahmed & Manuscript writing. \\
\hline 4 & Bushra Jabeen & Manuscript writing. \\
\hline 5 & M. llyas Shaikh & Literature search. \\
\hline 6 & Kinza Mushtaque & Literature search.
\end{tabular}

